\title{
NOVOS HORIZONTES
}

Nascemos do desejo de um amplo diálogo internacional — interdisciplinar, público, gratuito, livre de qualquer restrição institucional e dedicado a um leitor humanista — entre a filosofia e a ciência. No início, eram apenas um pesquisador argentino ligado à Universidad de Mar del Plata, uma pesquisadora brasileira da Universidade Federal de São Paulo (UNIFESP) e um grande sonho. Aos poucos, alguns amigos de outras universidades foram se aproximando e, em 2010, a revista lançou seu primeiro número num site em HTML sediado na Argentina com artigos em português e espanhol avaliados às cegas pelos pares.

Em 2011 e 2012, novos colegas dos dois países foram agregados à equipe editorial, possibilitando enfrentarmos novos desafios. Mudamos para um domínio internacional, passamos a editar nossa revista pela plataforma Open Journal System (OJS) e começamos a ser avaliados pelos portais indexadores.

De 2013 a 2018, agregamos mais dois membros à equipe, atribuímos a um terceiro as funções de editor-chefe, nos credenciamos em novos indexadores, adotamos o sistema de navegação criptografada (https://), iniciamos o uso de programas antiplágio nas avaliações, adotamos o DOI (Digital Object Identifier) e passamos a publicar artigos também em inglês, agora em três formatos diferentes: PDF, HTML e XML.

No segundo semestre de 2018, mais maduros e mais estruturados, iniciamos negociações visando sediar nossa revista no Portal de Periódicos da UNIFESP. Todas as tratativas se deram com base no respeito institucional à linha editorial da revista, à autonomia da equipe, a seu caráter internacional, com editores ligados a universidades de diferentes países, e às regras e padrões internacionais de qualidade editorial.

Assim, é com grande satisfação que anunciamos: ao longo do primeiro semestre de 2019, a Prometeica - Revista de Filosofia e Ciências migrará para o Portal de Periódicos da Universidade Federal de São Paulo. Em consequência, passaremos a integrar o Repositório de Dados de Pesquisa (RDP) da UNIFESP e a Indexação Compartilhada de Artigos de Periódicos (ICAP). Estaremos, então, vinculados à política de preservação digital e, portanto, interligados à rede internacional de repositórios; e teremos à disposição novas ferramentas, como o Pergamum - Sistema Integrado de Bibliotecas, o antiplágio Turnitin e a versão atualizada do Open Journal System.

Com isto, o horizonte acadêmico e internacional da Prometeica se expande exponencialmente, possibilitando novas metas de crescimento, desenvolvimento e consolidação.

Flaminio de Oliveira Rangel

(Universidade Federal de São Paulo) 